\title{
Spatial patterns of light gaps in mesic grasslands
}

\author{
JUSTIN D. DERNER AND X. BEN WU
}

Authors are Rangeland Scientist, USDA-ARS, High Plains Grasslands Research Station, Cheyenne, Wyo., 82009 and Associate Professor, Department of Rangeland Ecology and Management, Texas A\&M University, College Station, Tex., 77843-2126. At time of research, lead author was a Rangeland Scientist, USDA-ARS, Grassland, Soil and Water Research Laboratory, Temple, Tex., 76502-9601.

\section{Abstract}

The spatial pattern of light gaps in mesic grasslands in central Texas with contrasting disturbance histories was assessed using patch-based landscape metrics determined from a threshold level (25\% of full sunlight), as light intensities below this threshold substantially decrease survival of honey mesquite (Prosopis glandulosa var. glandulosa Torr.) seedlings. The spatial pattern of light gaps, with the exception of edge density, were significantly different between annually-disturbed and non-disturbed grasslands on all sample dates (2 April, 30 April, 29 May, and 26 June 1998). Differences in patch metrics did not occur between nondisturbed grasslands despite contrasting vegetation composition [perennial forbs and perennial bunch (tussock) grasses]. Patchbased landscape metrics of light gaps did vary temporally in both annually-disturbed and non-disturbed grasslands. The structure and spatial configuration of light gaps were distinctly different between annually-disturbed and non-disturbed grasslands: a low density of large patches characterized light gaps in annually-disturbed grassland, whereas non-disturbed grasslands had a high density of small patches. Our findings demonstrate that the current disturbance regime is the principal environmental driver influencing species dominance and composition, and indirectly vegetation structure, which collectively contribute to the observed dynamics of light gap patches in these mesic grasslands. Incorporating spatially explicit consideration of light gap structure and dynamics into experimental studies addressing invasion of weedy plant species such as honey mesquite may be an effective approach to address mechanisms and the ecological significance of disturbance operating as a driver facilitating woody plant invasions in mesic grasslands.

Key Words: disturbance history, patch metrics, Prosopis glandulosa, tallgrass prairie, woody plant

Invasion by non-resident species into grasslands is a global phenomenon with tremendous consequences to ecosystem structure and function (Vitousek et al. 1996, Dukes and Mooney 1999, Smith and Knapp 1999, Symstad 2000). Predictive capacity for assessing invasibility of grasslands, however, has been hindered

Authors wish to thank Jeff Posvar and Tommy Greeson for assistance in data collection and entry. We thank Darrel Ueckert and Keith Owens for insightful reviews of an earlier draft of the manuscript.

The United States Department of Agriculture (USDA) prohibits discrimination in all its programs and activities on the basis of race, color, national origin, gender, religion, age, disability, political beliefs, sexual orientation, and marital or family status.

Manuscript accepted 20 Oct. 03

\section{Resumen}

El patrón espacial de los huecos de luz en los pastizales mésicos de la región central de Texas con historias de disturbio contrastantes fueron evaluadas usando métricas de paisaje basadas en parches determinadas de un nivel de umbral $(25 \%$ de luz solar total), las intensidades de luz abajo de este nivel decrecen substancialmente la supervivencia de las plántulas de "Mesquite" (Prosopis glandulosa var. glandulosa Torr.). El patrón espacial de los huecos de luz, con excepción de la densidad en la orilla, fueron significativamente diferentes entre pastizales disturbados anualmente y pastizales sin disturbio, esto fue para todas las fechas de muestreo (2 de Abril, 30 de Abril, 29 de Mayo y 26, de June de1998). No ocurrieron diferencias en las métricas del parche entre pastizales sin disturbio, a pesar de la composición contrastante de la vegetación [hierbas perennes y zacates perennes amacollados]. Las mediciones de los huecos de luz del paisaje basadas en parches varían temporalmente tanto en pastizales con disturbio anual como en pastizales sin disturbio. La estructura y configuración espacial de los huecos de luz fueron distintivamente diferentes entre los pastizales con disturbio anual y los pastizales sin disturbio: una baja densidad de grandes parches caracterizó los huecos de luz en los pastizales disturbados anualmente, mientras que los pastizales sin disturbio tenían una alta densidad de parches pequeños. Nuestros hallazgos demuestran que el régimen actual de disturbio es la principal fuerza ambiental que influye en la dominancia de especies y la composición e indirectamente en la estructura de la vegetación, lo cual contribuye colectivamente a las dinámicas observadas de los parches de huecos de luz de estos pastizales mésicos, incorporando la consideración espacial explicita de la estructura de los huecos de luz y sus dinámicas dentro estudios experimentales que aborden la invasión de especies de maleza tales como el "Mesquite" puede ser un enfoque efectivo para estudiar los mecanismos y la significancia ecológica del disturbio operando como un factor que facilita la invasión de plantas leñosas en los pastizales mésicos.

by the complex interaction of several factors, including climatic variability, disturbance regime of the ecosystem, vegetation structure and composition, competitive ability of the invasive and resident species, life history attributes of the invasive species, and propagule availability (Rose et al. 1998, Lonsdale 1999, Smith and Knapp 1999, Davis et al. 2000, DiTomaso 2000, PrieurRichard and Lavorel 2000, Symstad 2000).

Disturbance has been well studied in many systems (White 1979, Sousa 1984), including mesic grassland ecosystems (Collins 1987, 2000, Glenn and Collins 1992). Although disturbance produces canopy gaps in vegetation and light gaps at the 
soil surface (Pickett and White 1985, Van Andel et al. 1987), the influence of disturbance on spatial attributes of these gaps in grassland ecosystems has received little attention. Studies addressing this issue are needed to increase understanding of the mechanisms involved in plant invasion.

Spatial patterns of light distribution in grasslands have recently been evaluated (Silvertown and Smith 1988, Tang and Washitani 1995, Anten and Hirose 1999, Skálová et al. 1999, Derner and Wu 2001), and these patterns can be viewed as discrete patches of light gap vs. non-light gap areas that are classified using a relevant threshold level of light intensity. Patchbased landscape metrics (Gustafson 1998) can be used to quantify the spatial attributes of such light "landscapes". The leguminous shrub, honey mesquite (Prosopis glandulosa var. glandulosa Torr.), has encroached into, and subsequently dominated, many of the temperate and subtropical grasslands and savannas of southern North America (Archer 1994, Van Auken 2000). This invasion has occurred only in recent history (Archer 1989), with the area invaded larger than for any other woody species in the semiarid grasslands of southwestern North America (Van Auken 2000). Although seedlings of honey mesquite emerge over a range of light regimes (Scifres et al. 1973, Brown and Archer 1989), survival percentage of these seedlings decreases substantially when light quantity at the soil surface is reduced to $25 \%$ of full sunlight (Scifres et al. 1973, Brown and Archer 1989, but see Bush and Van Auken 1987). Therefore, the light intensity value of $25 \%$ could be utilized as a threshold level to classify light gap (areas where light intensity is $>25 \%$ of full sunlight) and non-gap areas in mesic grasslands that may also serve as a preliminary assessment regarding the potential invasibility of honey mesqute in mesic grasslands.

This paper addresses the influence of disturbance on the spatial pattern of light gaps based on patch-based landscape metrics in mesic grasslands of central Texas. Previous results from these grasslands indicated that disturbance history affected spatial heterogeneity and temporal dynamics of light distribution at the soil surface (Derner and Wu 2001).

Therefore, our objectives were to: (1) utilize patch metrics derived using the $25 \%$ light intensity threshold to assess spatial patterns of light gaps and (2) use the resulting information to provide insight into the potential invasibility of honey mesquite in mesic grasslands. We tested the hypothesis that spatial patterns of light gaps would differ between grasslands with contrasting disturbance histories.

\section{Materials and Methods}

This study was conducted on 3 mesic grasslands with different disturbance regimes at the Grassland, Soil and Water Research Laboratory near Riesel, Tex. $\left(31^{\circ}\right.$ $\left.28^{\prime} \mathrm{N} ; 96^{\circ} 52^{\prime} \mathrm{W}\right)$. Long-term (62 year) mean annual precipitation is $89.6( \pm 22.0$, $1 \mathrm{SD}) \mathrm{cm}$, with peaks in May and October. Precipitation for 1997 was $19 \%$ above normal, but was $17 \%$ below normal for January-June in 1998. The 3 grasslands were: (1) native tallgrass prairie that receives an annual disturbance of haying in late June; (2) native tallgrass prairie that was annually disturbed by haying prior to 1985 , but has been without disturbance since and (3) reverted tallgrass prairie that had been cultivated prior to 1939 , allowed to naturally revegetate and hayed annually from 1940-85, and without disturbance since 1985. The 3 grasslands are small $(<2$ ha), immediately adjacent to each other, and are surrounded by croplands or permanent pastures. None of these grasslands currently have an abundance of honey mesquite. This is likely the result of an annual haying treatment on the native, annually-disturbed grassland and the removal of large honey mesquite trees from the reverted, non-disturbed grassland in the early 1990's. However, there are hackberry (Celtis occidentalis $\mathbf{L}$.) trees present in the native, non-disturbed grassland. Soils of these grasslands are classified as Houston Black series (fine, smectitic, thermic Udic Haplusterts) that are moderately well drained, but very slowly permeable and occur on slopes of 1 to $3 \%$.

The native, annually-disturbed grassland represents a disturbance that is typical of this region and is dominated by late-seral vegetation for this tallgrass prairie: little bluestem [Schizachyrium scoparium (Michx.) Nash.] (32\% of peak biomass), yellow indiangrass [Sorghastrum nutans (L.) Nash] (14\%), Texas wintergrass [Nassella leucotricha (Trin. \& Rupr.) Barkworth] (9\%), meadow dropseed [Sporobolus compositus (Poir.) Merr.] (5\%), and sideoats grama [Bouteloua curtipendula (Michx.) Torr.] (4\%). Additionally, perennial forbs contribute $20 \%$ of peak biomass. Fertilizer has never been applied to this grassland. In the native, non-disturbed grassland, these high seral grasses have been mostly replaced by mid-seral forbs, including giant ragweed
(Ambrosia trifida L. var. texana Scheele.) (28\%), prairie coneflower [Ratibida columnifera (Nutt.) Wooten \& Standl.] (16\%), and Aster spp. (38\%). The disturbance regime for this grassland reflects the exclusion of human (e.g., haying) and natural (e.g., fire) disturbance regimes. In contrast to the 2 native grasslands, the reverted, non-disturbed grassland is largely dominated $(>95 \%)$ by little bluestem. This grassland represents a reclaimed cultivated land, which is commonplace in this region.

Seven, $1 \times 1 \mathrm{~m}$ plots were randomly located in each of the 3 grasslands on 20 March 1998. Photosynthetically active radiation was measured at ground level between 1200 and 1500 hours (CST) on 2 April, 30 April, 29 May, and 26 June 1998 with a SunScan Canopy Analysis System (Delta T Devices, Ltd. Cambridge, UK). The native, annually-disturbed grassland was hayed following the June sampling, thereby preventing additional sampling. The SunScan Canopy Analysis System is a linear quantum sensor with a wand that is $0.015 \mathrm{~m}$ wide $\mathrm{x} 1 \mathrm{~m}$ long and contains 64 photodiodes. The entire plot was sampled by locating transects at $5 \mathrm{~cm}$ increments on the east and north sides of the plot, resulting in 2,432 photosynthetically active radiation measurements per plot. A photosynthetically active radiation reading was taken above the canopy prior to and following plot readings and averaged to express measurements within each plot as relative light intensity (photosynthetically active radiation at soil surface/ above canopy photosynthetically active radiation) $\mathrm{x}$ 100).

The 2,432 relative light intensity measurements in each plot and the spatial coordinates of their locations were imported into ArcView GIS as a point theme, which was then spatially interpolated to generate a continuous surface of relative light intensity for each plot, a grid theme with $0.5 \times 0.5-\mathrm{cm}$ resolution. The Inverse Distance Weighted interpolator in ArcView Spatial Analyst (ESRI 1998) was used for spatial interpolation. Relative light intensity values at unsampled locations were determined with a weighted average of the relative light intensity values of the nearest 12 sampled locations. The weights were determined using the inverse of the distance between the unsampled location and each of the sampled locations. This is based on the concept of spatial continuity that on the average, samples close together are more similar than those that are farther apart (Isaaks and Srivastava 1989, Rossi et al. 1992). 
Interpolation of the point themes using variography and kriging (Isaaks and Srivastava 1989, Goovaerts 1997) was also explored but was not selected, as there were considerable variations in the experimental variograms for different plots. The selection and use of different variogram models would introduce subjectivity and variation among the relative light intensity surfaces of different plots generated using kriging.

Landscape metrics for each plot were calculated using the Patch Analyst extension for ArcView (Elkie et al. 1999). We used 8 patch-based landscape metrics to quantify the spatial attributes and dynamics of the light gap patches (areas with light intensity $>25 \%$ of full sunlight) in the plots: (1) percent plot area occupied by light gap patches; (2) density of light gaps (number of gaps $/ \mathrm{m}^{2}$ ); (3) mean patch size of light gaps $\left(\mathrm{m}^{2}\right)$; (4) standard deviation of mean light gap sizes; (5) largest patch index (percent plot area covered by the largest light gap); (6) edge density (amount of edge of light gaps in $\mathrm{cm}$ per $\mathrm{m}^{2}$ of plot area); (7) mean shape index that represents shape complexity (calculated as the perimeter to area square root ratio of the patch divided by 4 , the perimeter to area square root ratio of a square patch) and (8) mean nearest neighbor distance (mean of shortest edge-to-edge distances between each light gap and its neighbors, $\mathrm{cm}$ ).

Given the possible correlation between the repeated measurements for the plots, we used repeated measure analysis of variance to test the effect of grassland type treatment on each of the 8 metrics of the light gaps across the 4 dates, using the general linear model (GLM) procedure in SAS (SAS Institute 1994). Comparisons between metric means for pairs of grasslands were conducted using contrasts in GLM when there was a significant $(\mathrm{P} \leq$ 0.05 ) overall treatment effect for the metric. Selected comparisons between metric means for grassland pairs at specific dates were also conducted using contrasts in GLM because there were significant date by treatment interactions for the metrics.

\section{Results and Discussion}

The spatial pattern of light gaps based on patch-based landscape metrics, with the exception of edge density, were significantly different on all sample dates between the annually disturbed grassland and the non-disturbed grasslands (Fig. 1). In addition, absence of significant differences between the 2 non-disturbed grass- lands for the all of the patch metrics for a vast majority of the sample dates indicates that withholding disturbance for the past 13 years had similar effects on light gaps in these grasslands. This is surprising given the distinct differences between these 2 grasslands in disturbance history and the domination by perennial forbs in the native, non-disturbed grassland and the perennial bunch (tussock) grass in the reverted, non-disturbed grassland. Collectively, our findings clearly indicate that dynamics of light gap patches in these mesic grasslands result from disturbanceinduced changes to species dominance and composition, which modify vegetation structure. This is manifest in the influence that disturbance has on modifying plant spatial distribution and arrangement (van der Maarel 1996, Anten and Hirose 1999), plant species composition and architecture (Anten and Hirose 1999, Skálová et al. 1999), and litter and standing crop dynamics (Kleyer 1999, Xiong and Nilsson 1999, Symstad 2000).

The structure and spatial configuration of light gaps differed substantially between the annually disturbed and nondisturbed grasslands. First, the percent of plot area occupied by light gap patches was $>75 \%$ in the native, annually-disturbed grassland across all sample dates, and these values were 2-3 fold greater than those in non-disturbed grasslands (Fig. 1). This is attributable to the annual haying event which removes standing crop and, as a result, increases light penetration to the soil surface. Second, although the native, annually-disturbed grassland had a much greater percent of the plot area occupied by light gap patches, the number of gaps per plot in this grassland was only 7 $46 \%$ of those in non-disturbed grasslands. Therefore, mean patch size of light gaps was 5-46 times larger in the native, annually-disturbed grassland than those found in non-disturbed grasslands. Third, the size of an individual light gap patch was more variable in the native, annually-disturbed grassland than in non-disturbed grasslands, with the exception of the first sample date in April when all 7 plots were $100 \%$ gap. Fourth, the largest gap in the native, annually-disturbed grassland always occupied $>70 \%$ of the plot area across sampling dates, while this value did not exceed $30 \%$ for either of the non-disturbed grasslands. Fifth, edge density of patches did not differ between grasslands with different disturbance histories, despite large differences in the percent of plot area in gaps. Sixth, shape complexity of the patches in the native, annually-dis- turbed grassland was greater than in nondisturbed grasslands, with the exception of the first sample date in April. Seventh, the mean nearest neighbor distance between gaps in the native, annually-disturbed grassland was shorter than that for nondisturbed grasslands, suggesting greater aggregation of gaps. Collectively, these results demonstrate that the annually disturbed grassland is characterized by a low density of large patches of light gaps, whereas the non-disturbed grasslands have a high density of small patches.

A product of these structural and spatial differences in light gaps between the annually disturbed and non-disturbed grasslands is that plant establishment likely differs between these grasslands. Light gaps at the soil surface are recognized as important sites for plant establishment in grassland ecosystems (e.g., Aguilera and Lauenroth 1993, Morgan 1998), with both root biomass and belowground competition within light gap areas substantially reduced compared to non-gap areas (Cahill and Casper 2002). Gap size may influence plant establishment (e.g., Goldberg and Werner 1983, Morgan 1998), with species reproducing by clonal growth (e.g., rhizomatous grasses) being highly sensitive to patch size with a preference for small openings, whereas species with the ability to have large seed banks or abundant seed dispersal (e.g., annual grasses) are not affected by patch size (Kotanen 1997). Growth of seedlings is affected by gap size with greater growth in larger gaps (Morgan 1998). The influence of gap size on seedling establishment may vary with site productivity as evidenced by successful seedling establishment in smaller gaps in low productivity sites than in high productivity sites (Hitchmough et al. 1996). Plants trying to establish in light gap areas do, however, experience decreased soil moisture because of greater evaporation (e.g., Goldberg and Werner 1983). Although the annual disturbance of haying creates large patches of light gap areas that could be colonized by other plants, the timing of haying in mid- to late-June likely prevents successful establishment by other plants as the growing season is typically hot and dry following harvest which would decrease soil moisture in light gap areas. A management change from annual haying to infrequent or removal of haying on these grasslands may induce invasion of woody plant species into this grassland as light gap patches are currently present, and the removal of annual disturbance may be sufficient to allow successful establishment 

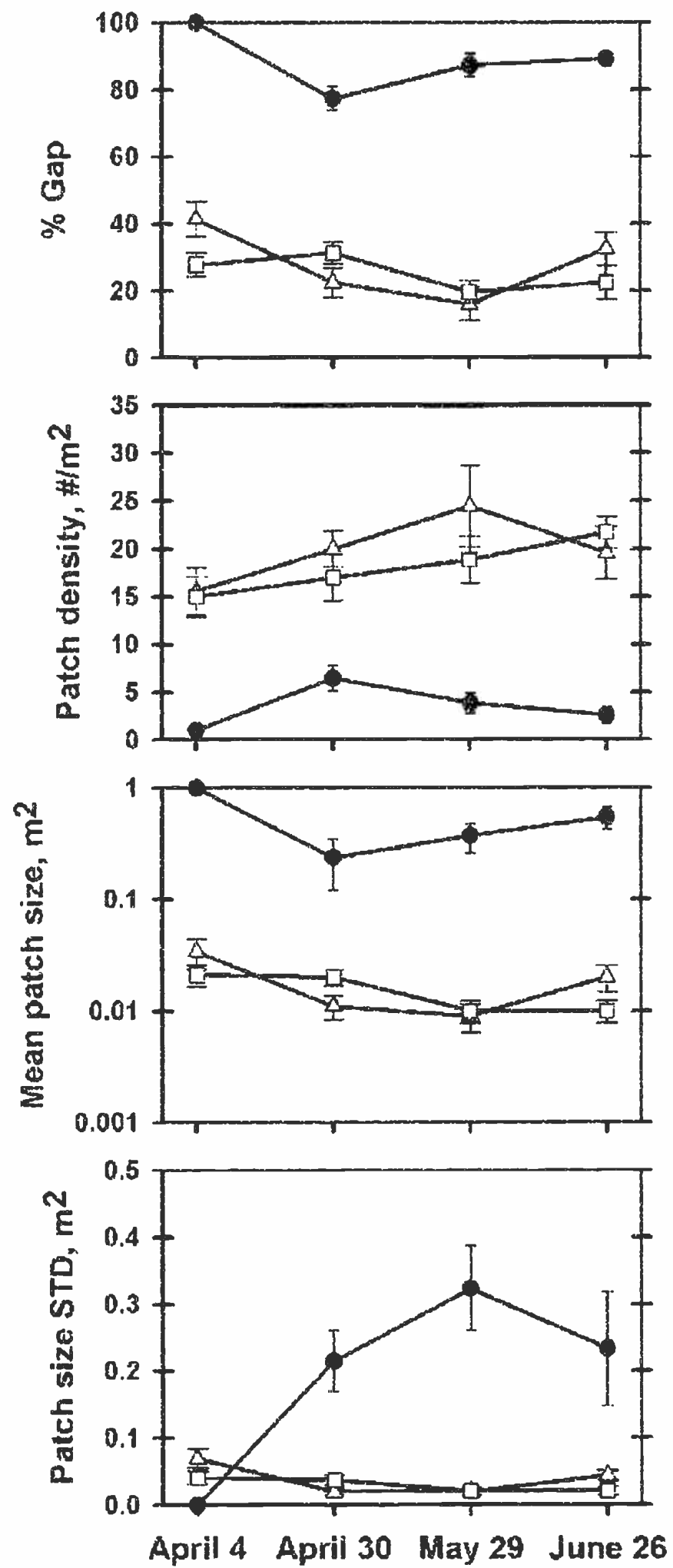
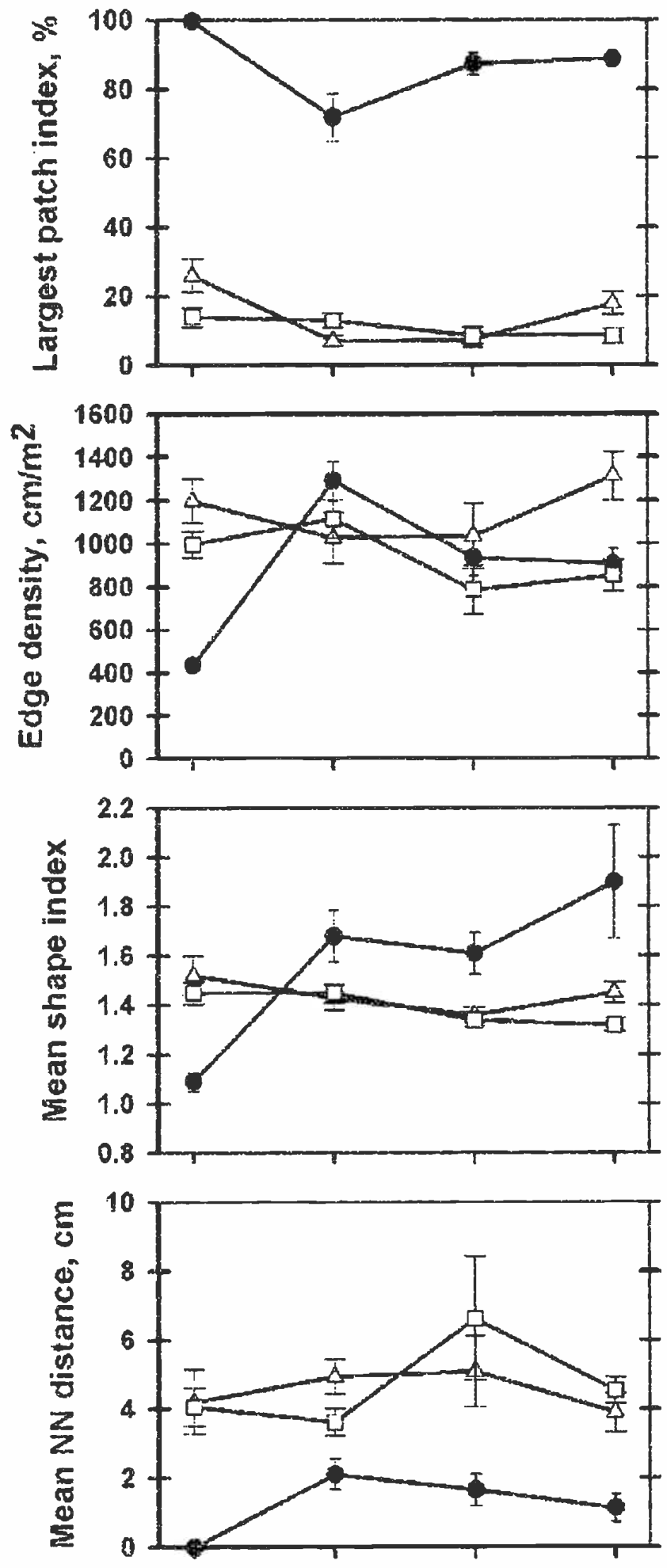

April 4 April 30 May 29 June 26

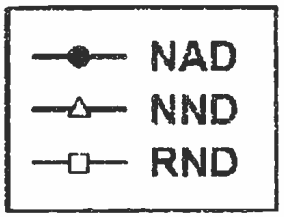

Fig. 1. Mean $\pm 1 \mathrm{SE}(\mathrm{n}=7)$ patch metrics of light gaps determined using a $25 \%$ light intensity threshold from $1 \times 1 \mathrm{~m}$ plots in 1$)$ a native, mesic grassland with annual disturbance of haying (NAD), 2) a native, mesic grassland without annual disturbance since 1985 (NND), and 3) a reverted (cultivated prior to 1939) grassland without disturbance since 1985 (RND). 
of woody plants. If the annual disturbance of haying was removed, we speculate that changes in canopy architecture would occur as a result of plant species compositional changes (e.g., Liira et al. 2002) to more perennial forbs, and these changes would be manifest in modifications to the structure and spatial configuration of light gaps as found in the non-disturbed grasslands.

Invasibility of plant communities is determined to a large extent by processes that create or close gaps (Goldberg and Gross 1988). We have demonstrated that disturbance clearly influences the structure and spatial pattern of light gaps in mesic grasslands. In addition, patch-based landscape metrics of light gaps varied temporally in both the annually-disturbed and non-disturbed grasslands (Fig. 1). Rates of gap creation and closure also varied throughout the growing season in a midsuccessional old field (Goldberg and Gross 1988), but size frequency distributions of light gaps differed little between spring and autumn in a New Zealand pasture (Panetta and Wardle 1992). Our finding that the patch metrics of light gaps were different between the annually disturbed and non-disturbed grasslands suggests that potential invasibility of these mesic grasslands by honey mesquite differs. Using light availability as the criterion, the native, annually-disturbed grassland has a much greater potential invasibility of honey mesquite as the \% gap per plot exceeding the $25 \%$ light intensity threshold is 2-3 times greater across sampling dates than in the non-disturbed grasslands. However, the annual disturbance of haying removes top growth, decreases soil moisture, and likely prevents successful invasion by this species. Conversely, in the non-disturbed grasslands, the absence of annual disturbance results in the accumulation of standing crop (Derner and Wu 2001) that decreases light availability to the soil surface and reduces patch area that may be potentially invaded by this woody plant. If we extrapolate these results using the light intensity threshold for honey mesquite to other woody plant species, it is apparent that other woody plant species will also be more likely to invade the annually disturbed than the non-disturbed grasslands because of the observed inherent differences in attributes of light gaps. We have previously speculated that the annually disturbed and non-disturbed grasslands would differ in susceptibility to invasion and in the identity of successful invaders because of differences in distribution of light, species composition and standing crop dynamics (Derner and Wu 2001), and sensitivity to disturbance impacts.

Our findings demonstrate that the current disturbance regime influenced species dominance and composition, thereby modifying vegetation structure, which influences the spatial pattern and dynamics of light gaps in these mesic grasslands. This concurs with our previous results that the spatial heterogeneity of light distribution was greater at all scales in the native, annually disturbed grassland than in the 2 non-disturbed grasslands (Derner and Wu 2001). Light gap structure and dynamics may explain, in part, the ecological role of disturbance in woody plant invasions of grasslands (e.g, Jurena and Archer 2003). As such, incorporating spatially explicit consideration of light gap structure and dynamics into experimental studies addressing invasion of weedy plant species may be an effective approach to address mechanisms, and the ecological significance of, disturbance as a driver facilitating woody plant invasions in mesic grasslands.

\section{Literature Cited}

Aguilera, M.O. and W.K. Lauenroth 1993. Seedling establishment in adult neighborhoods: intraspecific constraints in the regeneration of the bunchgrass Bouteloua gracilis. J. Ecol. 81:253-261.

Anten, N.P.R. and T. Hirose. 1999. Interspecific differences in above-ground growth patterns result in spatial and temporal partitioning of light among species in a tallgrass meadow. J. Ecol. 87:583-597.

Archer, S. 1989. Have Southern Texas savannas been converted to woodlands in recent history? Amer. Nat. 135:545-561.

Archer, S. 1994. Woody plant encroachment into southwestern grasslands and savannas: rates, patterns and proximate causes, $p$. 13-68. In: M. Vavra, W. Laycock and R. Pieper (eds.) Ecological Implications of Livestock Herbivory in the West. Soc. for Range Manage., Denver, Colo.

Brown, J.R. and S. Archer. 1989. Woody plant invasion of grasslands: establishment of honey mesquite (Prosopis glandulosa var. glandulosa) on sites differing in herbaceous biomass and grazing intensity. Oecologia 80:19-26.

Bush, J.K. and O.W. Van Auken. 1987. Light requirements for growth of Prosopis glandulosa seedlings. Southwestern Nat. 32:469-473.

Cahill, J.F. Jr. and B.B. Casper. 2002. Canopy gaps are sites of reduced belowground plant competition in a productive old field. Plant Ecol. 164:29-36.
Collins, S.L. 1987. Interaction of disturbances in tallgrass prairie: a field experiment. Ecol. 68:1243-1250.

Collins, S.L. 2000. Disturbance frequency and community stability in native tallgrass prairie. Amer. Nat. 155:311-325.

Davis, M.A., J.P. Grime, and K. Thompson 2000. Fluctuating resources in plant communities: a general theory of invasibility. J. Ecol. 88:528-534.

Derner, J.D. and X.B. Wu. 2001. Light distribution in mesic grasslands: Spatial patterns and temporal dynamics. Appl. Veg. Sci. 4:189-196.

DiTomaso, J.M. 2000. Invasive weeds in rangelands: species, impacts and management. Weed Sci. 48:255-265.

Dukes, J.S. and H.A. Mooney. 1999. Does global change increase the success of biological invaders? Trends Ecol. Evol. 14:135-139.

Elkie, P.C., R.S. Rempel, and A.P. Carr. 1999. Patch Analyst User's Manual. Ont. Min. Natur. Resour. Northwest Sci. \& Technol. Thunder Bay, Ont. TM-002. 16pp + Append.

ESRI. 1998. Working with ArcView Spatial Analyst. Environmental Systems Research Institute (ESRI), Inc. Redlands, Calif.

Glenn, S.M. and S.L. Collins. 1992. Effects of scale and disturbance on rates of immigration and extinction of species in prairies. Oikos 63:273-280.

Goldberg, D.E. and K.L. Gross. 1988. Disturbance regimes of mid-successional old fields. Ecol.. 69:1677-1688.

Goldberg, D.E. and P.A. Werner. 1983. The effects of size of opening in vegetation and litter cover on seedling establishment of goldenrods (Solidago spp.). Oecologia 60:149-155.

Goovaerts, P. 1997. Geostatistics for Natural Resources Evaluation. Oxford University Press, New York, N.Y., USA.

Gustafson, E. J. 1998. Quantifying landscape spatial pattern: What is the state of the art? Ecosystems 1:143-156.

Hitchmough, J.D., H. Curtain, L. Hammersley, and J. Kellow. 1996. Effect of gap width and turf type on the establishment of the Australian forb Bulbine bulbosa. Rest. Ecol. 4:25-32.

Isaaks, E.H. and R.M. Srivastava. 1989. An Introduction to Applied Geostatistics. Oxford University Press, New York, N.Y.

Jurena, P.N. and S. Archer. 2003. Woody plant establishment and spatial heterogeneity in grasslands. Ecol. 84:907-919.

Kleyer, M. 1999. Distribution of plant functional types along gradients of disturbance intensity and resource supply in an agricultural landscape. J. Veg. Sci. 10:697-708.

Kotanen, P.M. 1997. Effects of gap area and shape on recolonization by grassland plants with differing reproductive strategies. Can. J. Bot. 75:352-361

Liira, J., K. Zobel, R. Mägi, and G. Molenberghs. 2002. Vertical structure of herbaceous canopies: the importance of plant growth-form and species-specific traits. Plant Ecol. 163:123-134. 
Lonsdale, W.M. 1999. Global patterns of plant invasions and the concept of invasibility. Ecol. 80:1522-1536.

Morgan, J.W. 1998. Importance of canopy gaps for recruitment of some forbs in Themeda triandra-dominated grasslands in southeastern Australia. Aust. J. Bot. 46:609-627.

Panetta, F.D. and D.A. Wardle. 1992. Gap size and regeneration in a New Zealand dairy pasture. Aust. J. Ecol. 17:169-175.

Pickett, S.T.A. and P.S. White. 1985. The Ecology of Natural Disturbance and Patch Dynamics (eds). Academic Press, Orlando, Fla.

Prieur-Richard, A.H. and S. Lavorel. 2000. Invasions: the perspective of diverse plant communities. Austral Ecol. 25:1-7.

Rose, A.B., L.R. Basher, S.K. Wiser, K.H. Platt, and I.H. Lynn. 1998. Factors predisposing short-tussock grasslands to Hieracium invasion in Marlborough, New Zealand. New Zealand J. Ecol. 22:121-140.

Rossi, R.E., D.J. Mulla, A.G. Journel, and E.H. Franz. 1992. Geostatistical tools for modeling and interpreting ecological spatial dependence. Ecol. Mono. 62:277-314.
SAS Institute Inc. 1994. SAS/STAT User's Guide, Release $6.034^{\text {th }}$ Edition. SAS Institute, Inc., Cary, N.C.

Scifres, C.J., C.R. Kienast, and D.J. Elrod. 1973. Honey mesquite seedling growth and 2,4,5-T susceptibility as influenced by shading. J. Range Manage. 26:58-60.

Silvertown, J. and B. Smith. 1988. Gaps in the canopy: the missing dimension in vegetation dynamics. Vegetatio 77:57-60.

Skálová, H., F. Krahulec, H.J. During, V. Hadincová, S. Pechácková, and T. Herben. 1999. Grassland canopy composition and spatial heterogeneity in the light quality. Plant Ecol. 143:129-139.

Smith, M.D. and A.K. Knapp. 1999. Exotic plant species in a $\mathrm{C}_{4}$-dominated grassland: invasibility, disturbance, and community structure. Oecologia 120:605-612.

Sousa, W.P. 1984. The role of disturbance in natural communites. Ann. Rev. Ecol. Syst. 15:353-392.

Symstad, A.J. 2000. A test of the effects of functional group richness and composition on grassland invasibility. Ecol. 81:99-109.

Tang, Y. and I. Washitani. 1995. Characteristics of small-scale heterogeneity in light availability within a Miscanthus sinensis canopy. Ecol. Res. 10:189-197.
Van Andel, J., J.P. Bakker, and R.W. Snaydon. 1987. Disturbance in Grasslands. Causes, effects and processes (eds). Junk, Dordrecht.

Van Auken, O.W. 2000. Shrub invasions of North American semiarid grasslands. Ann Rev. Ecol. Syst. 31:197-215.

van der Maarel, E. 1996. Pattern and process in the plant community: Fifty years after A.S. Watt. J. Veg. Sci. 7:19-28.

Vitousek, P.M., C.M. D'Antonio, L.L. Loope, and R. Westbrooks. 1996. Biological invasions as global environmental change. Amer. Sci. 84:468-478.

White, P.S. 1979. Pattern, process, and natural disturbance in vegetation. Bot. Rev 45:229-299.

Xiong, S.J. and C. Nilsson. 1999. The effects of plant litter on vegetation: a meta-analysis. J. Ecol. 87:984-994. 